\title{
SIMPLICIA CHARACTERIZATION AND PHYTOCHEMICAL SCREENING OF SECONDARY METABOLITE COMPOUNDS ETHANOL EXTRACT OF TREMBESI LEAVES (Samanea Saman)
}

\author{
Zamharira Muslim ${ }^{1)^{*}}$, Heti Rais Khasanah ${ }^{1)}$, Yopita Sari ${ }^{1)}$ \\ Poltekkes Kemenkes Bengkulu
}

E-mail: zamhariramuslim@yahoo.com

Submitted: $13^{\text {th }}$ September 2021; Accepted: $14^{\text {th }}$ December 2021

https://doi.org/10.36525/sanitas.2021.12

\begin{abstract}
Trembesi plant (Samanea saman) is a plant that has the potential as traditional medicine. People that use medicinal plants often do not know the chemical content of these plants, so that in determining the amount of dosage, people only rely on experience and estimation. Research on the characterization of trembesi leaf simplicia has never been done. The purpose of this study was to determine the characteristics of trembesi leaf simplicia including specific and non-specific characteristics. The research is carried out in the laboratory using trembesi leaves. The research stages started from identifying the plant, making and extracting the simplicia, then determining specific and non-specific characteristics. In the phytochemical test, ethanol extract of trembesi leaves was used. Data analysis used is a descriptive method. Specific results showed trembesi leaf simplicia has a coarse powder form, distinctive odor, tasteless, green in color, and on microscopic results of trembesi leaf simplicia powder there is starch, fragments in the form of epidermis, water soluble extract content $11.93 \%$, ethanol soluble essence $18.93 \%$ and contains flavonoids, tannins, steroids and saponins. The results of non-specific characteristics are $8.07 \%$ water content, $7.91 \%$ ash content and $0.29 \%$ acid insoluble ash content.
\end{abstract}

Keywords: Trembesi, Phytochemicals, Secondary Metabolites

This is an open access journal, and articles are distributed under the terms of the Creative Commons AttributionNon Commercial-Share Alike 4.0 License, which allows others to remix, tweak, and build upon the work noncommercially, as long as appropriate credit is given and the new creations are licensed under the identical terms. (C)2021 Sanitas 


\title{
KARAKTERISASI SIMPLISIA DAN SKRINING FITOKIMIA SENYAWA METABOLIT SEKUNDER EKSTRAK ETANOL DAUN TREMBESI (Samanea saman)
}

\begin{abstract}
ABSTRAK
Tanaman trembesi (Samanea saman) merupakan tanaman yang berpotensi sebagai obat tradisional. Masyarakat dalam menggunakan tumbuhan obat seringkali tidak mengetahui kandungan kimia dari tumbuhan tersebut, sehingga dalam menentukan jumlah dosis pemakaiannya masyarakat hanya mengandalkan pada pengalaman dan perkiraan semata. Penelitian tentang karakterisasi simplisia daun trembesi belum pernah dilakukan. Tujuan dari penelitian ini untuk mengetahui karakteristik simplisia daun trembesi meliputi karakteristik spesifik dan non spesifik. Penelitian yang dilakukan berupa eksperimen di laboratorium. Sampel yang digunakan adalah daun trembesi. Tahapan penelitian dimulai dari identifikasi tumbuhan, pembuatan simplisia, ekstraksi, karakteristik spesifik dan non spesifik. Pada uji skrining fitokimia digunakan ekstrak etanol daun trembesi. Analisis data yang digunakan adalah metode deskriptif. Hasil karakteristik spesifik menunjukkan simplisia daun trembesi memiliki bentuk serbuk kasar, bau khas, tidak berasa, berwarna hijau kekuningan, dan pada hasil mikroskopik serbuk simplisia daun trembesi terdapat amilum, fragmen berupa epidermis, kadar sari larut air 11,93\%, kadar sari larut etanol 18,93\% serta mengandung flavonoid, tanin, steroid dan saponin. Hasil karakteristik non spesifik yaitu kadar air 8,07\%, kadar abu 7,91\% dan kadar abu tidak larut asam 0,29\%.
\end{abstract}

Kata Kunci: Trembesi, Fitokimia, Metabolit Sekunder.

\section{PENDAHULUAN}

Indonesia mempunyai beraneka ragam jenis tumbuhan. Banyak diantara tumbuhan tersebut telah dikenal oleh masyarakat Indonesia bermanfaat dalam pengobatan sehari-hari seperti daun sirih, serai, dan kemangi yang diketahui memiliki efek anti bakteri.(1) Salah satu tanaman yang memiliki manfaat sebagai obat adalah Trembesi. Trembesi banyak tumbuh di daerah tropis seperti daerah Sumatra. Penggunaan empiris yang diperoleh dari masyarakat setempat sebagai obat tradisional antara lain sebagai obat diare, demam, sakit perut, dan sakit kepala.(2) Informasi masyarakat tentang penggunaan tumbuhan trembesi masih sangat minim terutama pada bagian daun.

Penelitian sebelumnya terkait ekstrak daun Trembesi menyebutkan bahwa ekstrak tersebut dapat dimanfaatkan sebagai antijamur, antiseptik, antidiabetes, dan antibakteri.(3-5)(4) Ekstrak daun dari tumbuhan Trembesi mengandung senyawa flavonoid, tannin, steroid, saponin, terpenoid, dan glikosida kardiak. Hasil uji ekstrak daun trembesi terhadap pertumbuhan bakteri, diklaim mampu menghambat pertumbuhan bakteri Escherichia coli, Candida albicans, dan Staphylococcus aureus.(2) Penelitian ini bertujuan untuk mengetahui mutu dari suatu simplisia, dan dapat dijadikan sebagai acuan untuk pengembangan penelitian lanjutan. 


\section{METODE PENELITIAN}

Penelitian ini disajikan secara deskriptif kualitatif dan dilakukan dengan eksperimen di laboratorium. Penelitian dilakukan pada bulan Mei hingga Juni 2021 di Laboratorium Terpadu Poltekkes Kemenkes Bengkulu. Pengambilan sampel dilakukan di wilayah Kota Bengkulu.

Bahan yang digunakan pada penelitian ini yaitu serbuk simplisia dari daun Trembesi, etanol 70\%, asam asetat anhidrat, merkuri (II) klorida, besi (III) klorida, bismut (III) nitrate, Kalium Iodida, asam nitrat, asam klorida(p) 37\%, asam sulfat(p) 98\%, kloroform, etil asetat, iodium, magnesium, amil alkohol, kloralhidrat, aquadest.

\section{PROSEDUR PENELITIAN}

\section{Determinasi Tumbuhan}

Determinasi tanaman daun trembesi (Samanea saman) dilakukan di Laboratorium Biologi FMIPA Universitas Bengkulu dengan nomor: 45/UN30.12.LAB.BIOLOGI/PM/ 2021.

\section{Pembuatan Simplisia}

Langkah pertama adalah melakukan sortasi basah pada daun trembesi untuk memisahkan kotoran simplisia. Daun kemudian dicuci dengan air mengalir dan ditiriskan. Proses selanjutnya adalah mengeringkan simplisia di tempat yang terlindung dari sinar matahari. Simplisia kering dihaluskan dengan blender dan diayak dengan ayakan 40 mesh.

\section{Pembuatan Ekstrak}

Proses pembuatan ekstrak dilakukan dengan merendam sebanyak 300 gram simplisia daun trembesi kering dengan etanol 70\% dalam toples kaca. Perendaman diselingi dengan sesekali pengadukan selama 24 jam, selama 5 hari sampai semuanya terendam dalam maserator. Setelah 5 hari, rendaman disaring untuk memisahkan cairan dari residu dan diuapkan untuk menghasilkan ekstrak kental. 


\section{Pemeriksaan Karakterisasi Spesifik}

\section{Uji Makroskopik \& Mikroskopik}

Tujuan dari pengujian makroskopik adalah untuk mengetahui sifat-sifat simplisia dengan mengamati secara langsung bentuk, bau, rasa dan warna simplisia yang berupa serbuk daun. Pada uji mikroskopik, serbuk daun Trembesi diamati di bawah mikroskop. Serbuk diletakkan di atas kaca slide, ditetesi kloral hidrat, ditutup dan difiksasi pada lampu spiritus. Kemudian diamati adanya butiran pati dalam sel dan fragmen pembeda di tanaman.(5)

\section{Penetapan Kadar Sari Larut Etanol}

Sebanyak 5 gram serbuk simplisia direndam dalam $100 \mathrm{~mL}$ etanol $70 \%$ menggunakan labu gabus selama 24 jam, dikocok sesekali selama 6 jam pertama kemudian dibiarkan selama 18 jam. Sebanyak $20 \mathrm{~mL}$ filtrat disaring dengan cepat, diuapkan sampai kering dalam tara datar di atas alas datar, ditimbang dan dipanaskan sampai suhu $105^{\circ} \mathrm{C}$ sampai berat konstan.(5)

\section{Penetapan Kadar Sari Larut Air}

Serbuk Simplisia (5 gram) direndam dalam $100 \mathrm{~mL}$ kloroform P (2,5 mL kloroform dalam $100 \mathrm{~mL}$ akuades) menggunakan labu tertutup, kemudian dikocok sesekali selama 6 jam pertama, lalu dibiarkan beberapa saat. Setelah penyaringan cepat, $20 \mathrm{~mL}$ filtrat diuapkan sampai kering di atas penangas air dan sisanya dipanaskan $\left(105^{\circ} \mathrm{C}\right)$ hingga volume tetap. Konten dihitung sebagai persentase bahan yang dikeringkan di udara.(5)

\section{Pemeriksaan Karakterisasi Non Spesifik}

\section{Penetapan Susut Pengeringan}

Simplisia sebanyak 1 gram ditimbang hati-hati dan dimasukkan ke dalam krus porselen bertutup yang telah dipanaskan terlebih dahulu pada suhu $105^{\circ} \mathrm{C}$ selama 30 menit dan dicairkan. Simplisia dalam krus porselen dikocok dan dipipihkan hingga krus merata. Masukkan ke dalam oven, buka tutup wadah, panaskan dari suhu $100{ }^{\circ} \mathrm{C}$ hingga $105{ }^{\circ} \mathrm{C}$, timbang dan ulangi pemanasan hingga berat konstan.(5)

\section{Penetapan Kadar Air}

Serbuk Simplisia sebanyak 1 gram dimasukkan ke dalam cawan dan dikeringkan dalam oven pada suhu $105^{\circ} \mathrm{C}$ selama 30 menit. Biarkan dingin dalam desikator selama 15 menit. Setelah pendinginan, berat yang diperoleh konstan dan dihitung kadar airnya.(6) 


\section{Penetapan Kadar Abu Total}

Uji kadar abu dilakukan dengan menimbang hingga 3 gram serbuk simplisia, dan menempatkannya dalam krus porselen yang telah dinyalakan dan diratakan. Crucible dinyalakan secara perlahan sampai arang habis, dipijarkan pada suhu $600^{\circ} \mathrm{C}$ selama 3 jam, kemudian didinginkan dan ditimbang sampai mencapai berat tertentu.(5)

\section{Penetapan Kadar Abu Tidak Larut Asam}

Abu yang diperoleh saat mengukur kadar abu direbus dalam $25 \mathrm{~mL}$ asam klorida encer selama 5 menit, bagian asam yang tidak larut dikumpulkan, disaring melalui wadah kaca atau kertas saring yang tidak dicairkan dengan berat yang diketahui, dan sisanya dipanaskan. Kemudian dinginkan dan timbang sampai bobot tertentu. Abu yang tidak larut asam dihitung berdasarkan bahan yang dikeringkan di udara.(5)

\section{Identifikasi Metabolit Sekunder}

\section{Identifikasi Flavonoid}

Sebanyak 2 gram ekstrak dicampur dengan $100 \mathrm{~mL}$ air mendidih, direbus selama 5 menit lalu disaring selagi panas. $5 \mathrm{~mL}$ filtrat dicampur dengan $0,1 \mathrm{~g}$ serbuk $\mathrm{Mg}, 1 \mathrm{~mL} \mathrm{HCl}$ pekat dan 2 $\mathrm{mL}$ amil alkohol, kemudian dikocok hingga terpisah. Jika muncul warna merah, kekuningan, atau jingga pada lapisan amil alkohol, tesnya positif.(7)

\section{Identifikasi Alkaloid}

Sejumlah 2 gram ekstrak uji diuapkan pada cangkir porselen untuk menghasilkan residu. Residu kemudian dilarutkan dalam $5 \mathrm{~mL} \mathrm{HCl} 2 \mathrm{~N}$. Larutan yang dihasilkan kemudian dibagi menjadi 3 tabung reaksi. Tabung reaksi 1: Campur dengan $2 \mathrm{NHCl}$, yang bertindak sebagai nilai kosong. Tabung reaksi 2: Tambahkan 3 tetes pereaksi Dragendorff untuk menghasilkan endapan oranye. Tabung Reaksi 3: 3 tetes pereaksi Mayer ditambahkan untuk menghasilkan endapan putih sampai kekuningan. Jika endapan jatuh dari kedua pereaksi, dinyatakan positif mengandung alkaloid.(8)

\section{Identifikasi Steroid}

Sejumlah 2 gram ekstrak sampel dimasukkan ke dalam tabung reaksi, kemudian ditambahkan $2 \mathrm{~mL}$ etil asetat dan dikocok. Lapisan etil asetat dihilangkan, kemudian diteteskan pada plat tetes dan dikeringkan. Setelah kering, ditambahkan 2 tetes asetat anhidrida dan 1 tetes 
asam sulfat pekat. Jika terbentuk warna merah atau kuning, berarti positif terpenoid. Jika terbentuk warna hijau, berarti steroid positif.(9)

\section{Identifikasi Saponin}

Sebanyak 1 gram ekstrak dimasukkan ke dalam tabung reaksi ditambahkan $10 \mathrm{~mL}$ air panas, didinginkan kemudian dikocok kuat-kuat selama 10 detik. Larutan positif mengandung saponin jika terbentuk buih setinggi $110 \mathrm{~cm}$ tidak kurang 10 menit. Pada penambahan 1 tetes larutan asam klorida $2 \mathrm{~N}$, apabila buih tidak hilang menunjukkan adanya saponin.(9)

\section{Identifikasi Tanin}

Sebanyak 1 gram ekstrak dimasukkan ke dalam tabung reaksi ditambahkan $10 \mathrm{~mL}$ air panas kemudian dididihkan selama 5 menit kemudian filtratnya ditambahkan $\mathrm{FeCl} 3$ 1\% 34 tetes. Jika berwarna hijau biru (hijau - hitam) berarti positif adanya tanin katekol sedangkan jika berwarna biru-hitam berarti positif adanya tanin pirogalol.(9)

Tabel 1. Hasil Pemeriksaan Parameter Spesifik Simplisia Daun Trembesi

(Samanea saman).

\begin{tabular}{cc}
\hline \multicolumn{1}{c}{ Parameter } & Hasil Uji \\
\hline Uji Makroskopik & \\
\hline Bentuk & Serbuk agak kasar \\
\hline Warna & Hijau agak kekuningan \\
\hline Bau & Bau khas \\
\hline Rasa & Hambar/tidak ada rasa \\
\hline & Terdapat butiran amilum \\
\cline { 2 - 2 } Uji Mikroskopik & Terdapat rambut penutup \\
\cline { 2 - 2 } & Terdapat berkas pembuluh \\
\hline Penetapan Kadar Sari & \\
\hline Kadar sari larut air & $12,68 \%$ \\
\hline Kadar sari larut etanol & $19,24 \%$ \\
\hline
\end{tabular}




\section{HASIL DAN PEMBAHASAN}

\section{Uji Parameter Spesifik}

Uji parameter khusus dilakukan pada beberapa pengujian, antara lain uji makroskopis, uji mikroskopis, dan penetapan kadar ekstrak Simplisia. Tabel 1 menunjukkan hasil pengujian parameter spesifik simplisia daun trembesi. Uji makroskopik ini dilakukan pada serbuk simplisia daun trembesi dengan mengamati secara visual bentuk, bau, rasa dan warna serbuk simplisia. Pemeriksaan makroskopik bentuk simplisia serbuk daun trembesi agak kasar, berwarna hijau kekuningan, dengan bau yang nyata dan tidak berasa. Mikroskopi, di sisi lain, digunakan untuk menentukan apakah isi sel memiliki butiran pati dan sampel daun Trembesi memiliki fragmen pembeda. Pemeriksaan mikroskopis mengungkapkan fragmen pembeda granula pati dan daun Trembesi, yaitu mantel rambut dan ikatan pembuluh.

Ekstrak larut air dan kadar etanol merupakan pengujian untuk menentukan jumlah senyawa yang dapat larut dalam air dan pelarut etanol untuk mempermudah.(10) Hasil pengujian kadar ekstrak larut air simplisia daun trembesi diperoleh nilai rata-rata 12,68\%, dan kadar ekstrak larut etanol 19,24\%. Kandungan ekstrak larut etanol yang diperoleh lebih tinggi dibandingkan dengan ekstrak larut air. Ini berarti bahwa karena air bersifat polar dan etanol bersifat semi-polar, maka lebih banyak senyawa kimia yang larut dalam etanol daripada yang larut dalam air. Etanol dapat menarik senyawa polar dan non-polar, berbeda dengan air, yang hanya dapat menarik senyawa polar.

\section{Uji Parameter Non Spesifik}

Pengujian parameter non spesifik dilakukan pada banyak pengujian seperti uji kadar air, uji susut kering, kadar abu, dan kadar abu tidak larut asam. Tabel 2 menunjukkan hasil uji parameter non-spesifik Trembesi. Penentuan kadar air dimaksudkan untuk menentukan batas atas atau range kadar air simplisia. Rata-rata kadar air daun trembesi sebesar 8,41\%, menunjukkan bahwa kadar air serbuk simplisia daun trembesi memenuhi syarat kadar air. Kadar air yang dibutuhkan simplisia menurut parameter standar yang berlaku adalah kurang dari 10\% (10). Jika kadar air terlalu tinggi, mikroorganisme dapat tumbuh karena reaksi enzimatik yang dapat memecah bahan aktif. 
Tabel 2. Hasil pengujian parameter non-spesifik simplisia Daun Trembesi

(Samanea saman).

\begin{tabular}{llc}
\hline No & \multicolumn{1}{c}{ Uraian } & Hasil \\
\hline 1 & Kadar air & $8,41 \%$ \\
2 & Susut pengeringan & $8,66 \%$ \\
3 & Kadar abu & $8,36 \%$ \\
4 & Kadar abu tidak larut asam & $0,22 \%$ \\
\hline
\end{tabular}

Susut kering merupakan parameter non spesifik yang dimaksudkan untuk memberikan batas (range) maksimum terhadap jumlah senyawa yang hilang dalam proses pengeringan. Parameter susut pengeringan pada dasarnya adalah ukuran bahan sisa setelah pengeringan sampai berat tertentu pada suhu $105^{\circ} \mathrm{C}$ dan dinyatakan dalam persen.(10) Saat menentukan parameter susut kering untuk simplisia, susut kering rata-rata adalah 8,66\%. Massa yang dapat hilang dengan pemanasan ini termasuk molekul air, minyak atsiri, dan pelarut etanol.(10) Pengukuran abu dan abu tidak larut asam dimaksudkan untuk menentukan apakah perlakuan tersebut sesuai dan untuk menguraikan kandungan mineral di dalam dan di luar simplisia.(10) Hasil penetapan kadar abu simplisia daun trembesi diperoleh nilai rata-rata yaitu 8,36\%.

Penentuan kadar abu dan kadar abu tidak larut asam bertujuan untuk memberikan gambaran kandungan mineral internal dan eksternal yang terkandung dalam simplisia dan juga mengetahui jumlah abu yang tidak larut dalam asam, misalnya logam berat, pasir dan tanah silikat (6). Hasil penetapan kadar abu tidak larut asam yaitu $0,22 \%$. Besarnya kadar abu dan kadar abu tidak larut asam menunjukkan adanya pengotor yang berasal dari logam berat, pasir atau tanah silikat pada simplisia. Faktor ini dapat disebabkan oleh suhu ruang pada saat penimbangan atau kondisi lingkungan dan tempat tumbuh dari tanaman trembesi yang mengandung unsur hara yang tinggi (7).

\section{Uji Skrining Fitokimia}

Untuk mengetahui kandungan metabolit sekunder yang dikandung oleh simplisia daun Trembesi dilakukan beberapa uji kimia kualitatif (Tabel 3). 
Tabel 3. Hasil Skrining Fitokimia Ekstrak Simplisia Daun Trembesi

(Samanea saman)

\begin{tabular}{cllll}
\hline Uji & \multicolumn{1}{c}{ Reagen } & Pengamatan & \multicolumn{1}{c}{ Standar } & Hasil \\
\hline Alkaloid & Dragendorf & $\begin{array}{l}\text { Endapan } \\
\text { jingga } \\
\text { Endapan putih } \\
\text { kekuningan }\end{array}$ & $\begin{array}{l}\text { Endapan jingga } \\
\text { Endapan putih } \\
\text { kekuningan }\end{array}$ & $(+)$ \\
\hline Flavonoid & $\begin{array}{l}\text { Serbuk } \\
\mathrm{Mg}^{2} \mathrm{HCl}_{(\mathrm{p})}+ \\
\text { amil alkohol }\end{array}$ & Warna jingga & $\begin{array}{l}\text { Warna merah, } \\
\text { kekuningan, jingga }\end{array}$ & $(+)$ \\
\hline Saponin & $\begin{array}{l}\text { Air panas, } \\
\text { dikocok kuat 10 } \\
\text { detik+HCl 2N }\end{array}$ & $\begin{array}{l}\text { Adanya buih } \\
\text { permanen 5 } \\
\text { cm }\end{array}$ & $\begin{array}{l}\text { Adanya buih } \\
\text { permanen 1 -10 cm }\end{array}$ & $(+)$ \\
\hline \multirow{2}{*}{ Tanin } & $\begin{array}{l}10 \mathrm{~mL} \text { aquadest } \\
+\mathrm{FeCl} 1 \%\end{array}$ & $\begin{array}{l}\text { Hijau } \\
\text { kehitaman }\end{array}$ & $\begin{array}{l}\text { Hijau biru/hijau } \\
\text { kehitaman (katekol), } \\
\text { biru hitam(pirogalol) }\end{array}$ & $(+)$ \\
\hline Steroid & $\begin{array}{l}\text { Etil asetat }+ \\
\text { asam asetat } \\
\text { anhidrat }+\mathrm{HCl}_{(\mathrm{p})}\end{array}$ & Warna hijau & $\begin{array}{l}\text { Hijau(steroid), } \\
\text { merah/kuning } \\
\text { (terpenoid), }\end{array}$ & $(+)$ \\
\hline
\end{tabular}

Pada uji senyawa alkaloid ekstrak etanol daun trembesi memberikan hasil positif. Filtrat yang ditetesi dengan pereaksi dragendorf menunjukkan adanya endapan jingga sedangkan filtrat yang ditetesi dengan pereaksi mayer menunjukkan adanya warna putih kekuningan. Jika terbentuk endapan dari 2 hingga 3 pengujian kualitatif alkaloid, maka dapat disimpulkan positif.(8) Penelitian lain yang menggunakan daun trembesi juga menyampaikan hasil yang sama bahwa mengandung alkaloid.(9) Alkaloid pada tanaman memiliki banyak kegunaan sebagai bahan awal obat. Beberapa kegunaan alkaloid sebagai terapi penyakit diabetes, hipertensi, aritmia, malaria, kanker, dan lainnya. $(9,10)$

Uji flavonoid ekstrak etanol daun trembesi menunjukkan hasil positif pada lapisan amil alkohol yang menunjukkan adanya flavonoid. Penambahan serbuk magnesium dan asam klorida pekat pada uji flavonoid mengurangi senyawa flavonoid yang ada sehingga menimbulkan reaksi berwarna merah, kuning, atau jingga yang merupakan tanda adanya flavonoid.(14) Metabolit sekunder dari flavonoid dapat mengobati diabetes dengan menghambat kerja enzim-glukosidase dalam memecah karbohidrat menjadi monosakarida dan sebagai antioksidan untuk mengurangi stres oksidatif pada pasien diabetes. 
Pengujian saponin memberikan hasil positif yaitu adanya busa yang stabil dan permanen dengan penambahan $\mathrm{HCl} 2 \mathrm{~N}$. Hal ini dikarenakan senyawa saponin terdiri dari senyawa yang larut dalam air (hidrofobik) sehingga secara fisika senyawa saponin bersifat sebagai surfaktan yang dapat menurunkan tegangan permukaan air. Penurunan tegangan permukaan air inilah yang mengakibatkan terbentuknya busa pada permukaan air setelah dikocok.(11) Saponin telah dilaporkan memiliki berbagai aktivitas biologis, seperti insektisida, toksik untuk serangga, parasit cacing, mollusca, antijamur, antivirus, dan antibakteri.(10)

Uji tanin pada penambahan $\mathrm{FeCl}_{3} 1 \%$ memberikan hasil positif yaitu adanya perubahan warna hijau kehitaman. Hal ini dikarenakan senyawa tanin membentuk kompleks dengan larutan feriklorida $\left(\mathrm{FeCl}_{3}\right)$ menghasilkan warna hijau kehitaman yang berarti adanya senyawa tanin galat (tanin terhidrolisis).(12) Tanin digunakan dalam industri zat warna sebagai caustic untuk pewarna kationik (tanin pewarna), dan juga dalam produksi tinta. Kegunaan skala industri lainnya dari tanin termasuk di dalamnya pewarna tekstil, ialah seperti anti-oksidan dalam industri jus buah, bir dan anggur dan sebagai koagulan dalam produksi karet.(10)

Senyawa steroid apabila ditambahkan asam asetat anhidrat dan asam sulfat pekat akan membentuk warna hijau atau hijau kebiruan.(13) Pada pengujian senyawa steroid memberikan warna hijau pada saat penambahan asam asetat anhidrat dan asam sulfat pekat yang menunjukkan hasil positif yaitu adanya senyawa steroid pada ekstrak etanol daun trembesi. Hal ini sesuai seperti yang dilaporkan (2) pada penelitiannya menunjukkan adanya senyawa steroid dalam ekstrak daun trembesi. Steroid memiliki khasiat anti-inflamasi, penenang, insektisida atau aktivitas sitotoksik.(14)

\section{SIMPULAN}

Uji parameter spesifik serbuk simplisia daun trembesi yaitu pengamatan makroskopik berupa serbuk agak kasar, hijau kekuningan, bau khas dan tidak berasa, pengamatan mikroskopik diketahui adanya butir-butir amilum, rambut penutup dan berkas pembuluh, serta dilakukan pengujian kadar sari larut air dan penetapan kadar sari larut etanol. Pengujian parameter non spesifik yang dilakukan yaitu penentuan kadar air, susut pengeringan, kadar abu, dan kadar abu tidak larut asam. Pemeriksaan fitokimia menunjukkan bahwa ekstrak etanol daun trembesi positif mengandung flavonoid, tanin, saponin, dan steroid. 


\section{DAFTAR PUSTAKA}

1. Suriawati J, Rachmawati R, Analisa J, Kesehatan P, Jakarta K, Raya J, Et Al. Antibacterial Activities Test Of Combination Of Ethanolic Extract Of Betel Leaves ( Piper Betle L .) And Basil Leaves ( Ocimum Basilicum L .) Against Staphylococcus Aureus ( Piper Betle L .) Dan Daun Kemangi ( Ocimum Basilicum L .) Terhadap Staphylococcus. Sanitas J Teknol Dan Seni Kesehat. 2018;09:118-26.

2. Prasad Rn, Viswanathan S, Devi Jr, Nayak V, Swetha Vc, Parathasarathy N, Et Al. Preliminary Phytochemical Screening And Antimicrobial Activity Of Samanea Saman. J Med Plants Res. 2008;2(10):268-70.

3. Tungadi R, Abdulkadir W. Burn Wound Healing Effect Of Trembesi (Samanea Saman) Leaves Extract Gel On Rats (Rattus Novergicus). Int J Pharmtech Res. 2015;7(4):601-5.

4. Puspita Sari P, Susanah Rita W, Puspawati N. Identifikasi Dan Uji Aktivitas Senyawa Tanin Dari Ekstrak Daun Trembesi (Samanea Saman (Jacq.) Merr) Sebagai Antibakteri Escherichia Coli (E. Coli). J Kim. 2015;9(1):27-34.

5. Vinodhini S, Rajeswari Vd. Exploring The Antidiabetic And Anti-Obesity Properties Of Samanea Saman Through In Vitro And In Vivo Approaches. J Cell Biochem. 2019;120(2):1539-49.

6. Departemen Kesehatan Ri. Direktorat Jendral Pengawasan Obat Dan Makanan. Parameter Standar Umum Ekstrak Tumbuhan Obat. 2000. 30-38 P.

7. Salim M, Yahya Y, Sitorus H, Ni'mah T, Marini M. Ubungan Kandungan Hara Tanah Dengan Produksi Senyawa Metabolit Sekunder Tanaman Duku (L. Domesticum Corr Var Duku). J Vektor Penyakit,. 2019;((1)):138.

8. Marjoni Mr. Dasar Dasar Fitokimia.Pdf. 2016. 39-43 P.

9. Setiawan Ma, Saehu Ms, Kartini K. Uji Efek Antidiabetik Ekstrak Daun Trembesi (Albizia Saman (Jacq.) Merr) Terhadap Mencit (Mus Musculus L). War Farm. 2019;8(2):43-52.

10. Saxena M, Saxena J, Nema R, Singh D, Gupta A. Phytochemistry Of Medicinal Plants. Med Plants Cent Asia Uzb Kyrg. 2013;1(6):13-4.

11. Zahro L, Agustini R. Uji Aktivitas Antibakteri Ekstrak Kasar Saponin Jamur Tiram Putih (Pleurotus Ostreatus) Terhadap Staphylococcus Aureus And Escherichia Coli. Unesa J Chem. 2013;2(3):120-9.

12. Sa'adah L. Isolasi Dan Identifikasi Senyawa Tanin Dari Daun Belimbing Wuluh (Averrhoa Bilimbi L.). Universitas Islam Negeri (Uin) Maulana Malik Ibrahim Malang; 2010.

13. Baxter H, Harborne Jb, Moss Gp. Phytochemical Dictionary: A Handbook Of Bioactive Compounds From Plants. Crc Press; 1998.

14. Doughari Jh. Phytochemical Constituents Of Some Selected Medicinal Plants. In: Phitochemicals: A Global Perspective Of Their Rule In Nutrition And Health. 2011. P. $15020-4$. 